\title{
Pap smear: understanding of rural women about the purpose and access
}

\author{
Exame citopatológico: compreensão de mulheres rurais acerca da finalidade e do acesso
}

Igho Leonardo do Nascimento Carvalho ${ }^{1}$, Renata Barbosa Nunes ${ }^{1}$, Isaura Danielle Borges de Sousa ${ }^{1}$, Rose Danielle de Carvalho Batista ${ }^{2}$, Antonia Sylca de Jesus Sousa ${ }^{1}$, Caroline da Silva Sousa ${ }^{1}$

Objective: to describe the understanding of rural women about the purpose and access to Pap smear. Methods: qualitative study conducted with 15 women. Data collection was carried out through a semi-structured interview script, by adopting content analysis. Results: the study found that women had insufficient understanding about the reason to perform the examination, both in the matter of prevention and regarding diagnosis of cervical cancer. Women have also demonstrated difficulties to perform the examination by the difficult access to the cytological examination and by the little frequency of the Family Health Strategy team in going the rural communities evaluated. Conclusion: the understanding of the purpose of Pap smear is insufficient and access is inappropriate. This condition is a risk to the onset of cervical cancer in rural women.

Descriptors: Knowledge; Health Services Accessibility; Papanicolaou Test; Uterine Cervical Neoplasms; Primary Health Care.

Objetivo: descrever a compreensão de mulheres rurais sobre a finalidade e o acesso ao exame citopatológico. Métodos: qualitativo, com 15 mulheres. Coleta realizada por meio de roteiro de entrevista semiestruturado, sendo adotada análise de conteúdo. Resultados: o estudo identificou que as mulheres tinham compreensão insuficiente sobre o motivo de realização do exame, tanto na questão da prevenção quanto no diagnóstico do câncer do colo do útero. Para conseguir realizar o exame, as mulheres também demonstraram ter dificuldades mediante o difícil acesso ao exame citopatológico e a pouca frequência da equipe Estratégia Saúde da Família às comunidades rurais avaliadas. Conclusão: a compreensão da finalidade do exame citopatológico encontra-se insuficiente e o acesso é inadequado. Essa condição representa um risco ao acometimento de câncer do colo do útero em mulheres rurais.

Descritores: Conhecimento; Acesso aos Serviços de Saúde; Teste de Papanicolaou; Neoplasias do Colo do Útero; Atenção Primária à Saúde.

\footnotetext{
${ }^{1}$ Universidade Federal do Piauí. Floriano, PI, Brazil.

${ }^{2}$ Secretaria Municipal de Saúde de Floriano. Floriano, PI, Brazil. 


\section{Introduction}

Cervical cancer appears as a major problem of public health worldwide. In this sense, the Pap smear screening is potent strategy for prevention and/or early detection of numerous gynecological problems, especially this type of cancer. Therefore, the understanding of its importance and women's access to the cytological examination are essential factors for adherence/routine performance of this examination and consequent change in the epidemiological profile of incidence of cervical cancer.

Cervical cancer has slow evolution and its natural history is described as a condition that is initially benign, which undergoes progressive intraepithelial transformations with an average time of 10 to 20 years, and it may evolve to invasive carcinoma. It is estimated the appearance of 529,000 new cases in the world annually, and in Brazil in 2016, it is expected 16,340 new cases and estimated risk of 15.85 cases per 100 thousand women ${ }^{(1)}$. Thus, cervical cancer is the third most common cancer in women, and the reduction of its prevalence, incidence and mortality is feasible by the detection of precursor lesions in asymptomatic women through Pap smear ${ }^{(2-3)}$.

The cervical cytology technique was developed and named by the pathologist George Nicholas Papanicolaou, who in 1941 published a complete description of the diagnostic approach. The Pap smear screening was quickly adopted by gynecologists and, at first, its only goal was detecting invasive carcinoma ${ }^{(4)}$.

Pap smear screening promotes early detection of premalignant lesions and invasive cancer through periodic cytological analysis of smear of ectocervical and endocervical epithelial cells. This examination incorporated into the National Oncological Care Policy is critical to the efficiency of an organized screening program with a set of programmed actions and a well-defined target population, age and frequency of realization of the examination ${ }^{(5)}$.

The Pap smear test is considered effective and efficient, but its coverage is still insufficient, due to several factors, such as beliefs, feelings, attitudes, socioeconomic aspects and accessibility. In this context, there is the influence of socioeconomic and cultural factors in the understanding of the relevance of this examination for prevention of cervical cancer and there is also the influence of its access in Primary Health Care $^{(6)}$.

The high prevalence and incidence of gynecological problems that can be early diagnosed by the Pap test in women living in rural areas suggest the existence of problems of understanding, accessibility and adherence to this examination that is available in Primary Health Care.

This study is based on the contribution to the development of preventive actions against cervical cancer in Primary Health Care, reducing or overcoming factors that make insufficient the coverage to women living in the countryside. This research intends to contribute to expanding the effectiveness of cervical cancer screening as it provides reflection on women's health based on accessibility, understanding and awareness of women about Pap smear. Thus, this study aimed to describe the understanding of rural women about the purpose of and access to the cytological examination.

\section{Methods}

This is qualitative research conducted with 15 rural women in the city of Floriano, located in the state of Piaui, one of the poorest states of the Brazilian Northeast, whose female population represents $52.6 \%$ of the total.

Women were selected randomly, and the saturation of the ideas set the number of participants, while the selection of the visited rural communities was held by lot and were grouped by geographic proximity to the urban area: two communities are located between 10 and $12 \mathrm{~km}$ from the urban area and two between 30 and $40 \mathrm{~km}$ from the urban area.

The included women had been living in the countryside for at least one year; were aged over 18 
and had performed at least one Pap smear screening through the National Health System. Women who were on schedule to return for the treatment of sexually transmitted infection and cervical cancer were excluded due to the required frequency of care provided by the Family Health Strategy team.

The collection took place in January 2016, through individual, semi-structured and face-to-face interview, lasting between 10 and 20 minutes during home visits by the researcher to women in rural communities. The interviews were audio recorded on a smartphone mobile device in order to facilitate the transcription of the answers of subjective questions; authors made grammatical and spelling corrections, without changing the meaning.

Researchers identified interviews in numerical order (Ex.: P1, P2, P3...) and used the content analysis technique, specifically thematic analysis, in which, for each answer, they identified a unit of meaning, which enabled content organization according to the similarity of ideas, and grouping into thematic categories, in which analysis occurred, based on literature $^{(7)}$.

The analysis plan covers the following thematic categories: understanding of the importance and access to the Pap smear screening. In each category, the main units of meaning were identified and widely compared to the scientific literature.

The study complied with the formal requirements contained in the national and international regulatory standards for research involving human beings.

\section{Results}

There are two categories: Rural women's understanding of Pap smear and Access to Pap smear. The first deals with the prevention and diagnosis offered by cytological examination, whereas the second deals with access to health education on the subject and to the examination itself.

\section{Rural women's understanding of Pap smear}

The study found that the understanding of rural women about Pap smear was based in two dimensions: prevention and diagnosis. The surveyed women understood that the first dimension was related to anticipation of disease and to the sense of fear from its discovery in late stage, while the second was related to the discovery of diseases, including cervical cancer. In this context, the ideas of concept, relevance and reason for seeking the Basic Health Unit for realization of the Pap smear screening were developed from the dimension of prevention or diagnosis.

Women believe that the Pap smear is useful for early discovery of the disease, justifying its relevance for the specific prevention of cervical cancer or for the prevention of other diseases. They have also reported spontaneous demand, without the presence of clinical manifestations suggestive of diseases, and that it could be related to a temporal periodicity. Yes I know, it is aimed to prevent some cancers such as cervical cancer (P1). Yes, because it will prevent many diseases (P11). I always try to do this examination every year. I do not like to wait until the problem appears (P6).

Women conceptualized the cytological examination in view of the diagnosis and the discovery of the disease, and reported it in three ways: discovery of cancer, without specifying the type of cancer; discovery of womb disease; and discovery of cervical cancer itself. Thus, it appears that rural women were unaware of the actual function of the diagnosis made by the Pap smear: I know, it is for that ugly disease, cancer, to know what we are feeling that we have, it finds out what we have (P3). Yes, it allows detecting diseases in the womb (P15).

The greatest demand of women in health service to perform cytological examination was justified by the need of diagnosis from the onset of clinical manifestations. This finding demonstrates that the use of the health service for carrying out preventive actions was not being understood by these 
women, as shown in the reports: I do it when I am feeling something, I do this way, I wait until feeling something (P3). We always have to seek it, I get worried about every little thing that I feel and I always seek improvements (P5).

As for the frequency required for Pap smear screening, women reported not knowing whether it is annually or biannually, and showed lack of confidence in the answer. This evidences, therefore, that rural women had insufficient or inadequate information about the frequency of performing the examination. I cannot know tell you (P3). I think it is every six months, doing so it is a good start (P4). I think it is every year, because once I asked the nurse and she said it was annually (P1).

\section{Access to Pap smear}

In the study, two dimensions of access were investigated: health education on the subject and cytological examination. It was found that these dimensions found to be inadequate, which shows the need for planning promotion and prevention actions related to the control of cervical cancer.

Participants said they have not participated in health education practice on cytological examination. The absence of health promotion practices through educational activities implies vulnerability of women due to insufficient or distorted understanding of the Pap smear and its relation to the prevention and early diagnosis of cervical cancer. They have never held lecture here no, they take too long even to come here to perform consultations; sometimes they take more than three months to come (P1). I do not remember, here it is very exposed; no one wants to say everything they are feeling in front of everyone (P7).

Study participants cited two arguments to justify the position of not considering as easy the access to the Pap smear: the examination is not carried out in the countryside, which requires traveling to the city and financial costs arising therefrom. And the delay of the Family Health Strategy team to perform services to the population in rural communities. They do come here then I'd rather go to town and schedule on my own at a health unit there, but sometimes when I say I live in the countryside they do not want to see me. And when I have no money I do not go and stay without prevention; I have to have at least fifteen reais to go and come (P8). They come here once in a life and never come again. So I do it in the health unit, in the city, on my own. And not to mention that I have to spend to go to; I have to pay to go to and also to get the result (P10). There is no prevention here, so to do it, I have to pay to go and to get the result I have to pay again; if I do not have money, I do not go (P14). I take the bus on my own, sometimes I even walk to another place where there are more buses. They do not do the prevention examination (P1).

\section{Discussion}

The study presents as limitation the selection of women in rural communities grouped by geographical distance from the urban area, since the selected communities may not reflect reliably the understanding about the purpose and access to Pap smear.

Women's perceptions in relation to this procedure interfere directly in their behavior when subjected to the examination, and the feelings generated are experienced in a unique way. Thus, the attitude of seeking early detection is determined by women's beliefs and perceptions about what health, disease and cytological examination are, and also by the experiences lived by them for prevention, maintenance and treatment of health ${ }^{(8-9)}$.

Pap smear is an important procedure for early detection of pre-invasive lesions and thus an essential tool for reducing mortality from this disease. The lack of understanding of the importance of this examination by a segment of women is a challenge for health services, as it provides limited access to screening for cervical cancer, especially in those women considered at higher risk ${ }^{(10)}$.

The difficult access to health services for women living in rural areas affect the early detection of major diseases through cytological examination, such as cervical cancer. In a survey conducted in the rural area of Karnataka, India, in the years 2013 and 2014 with 1020 women, it was observed that only $2.4 \%$ of sexually active women had been subjected to the Pap 
smear, despite the high literacy rate $(85.7 \%)^{(11)}$.

In gynecological nursing consultations, it is observed that women little understand the function of cervical cancer screening. The fact that women show embarrassment, anxiety, fear, concern about the examination has aggravated this situation. Thus, they seek to perform the exam when they are feeling some discomfort, such as vaginal discharge, itching, pain in the pelvic area, disturbed menstruation, among other complaints. This behavior interferes with the better outcome of the screening(8).

In the context of Health Care Networks, the Brazilian Ministry of Health has established four priority commitments, including the strengthening of actions for prevention and identification of diagnosis and treatment of cervical cancer ${ }^{(12)}$. In this sense, the different aspects related to the understanding of women about Pap smear should be guided by the combined concept of prevention and diagnosis, thus providing an effective knowledge for control of cervical cancer.

Women who have or have had sexual life and are between 25 and 64 years old should perform Pap smear screening. Because of the long evolution of cervical cancer, this examination may be performed every three years and for a safer diagnosis, the first two tests should be performed annually. If the results are normal, repetition will only be required after three years $^{(13)}$.

In Brazil, examinations still have been conducted in a timely manner, with the spontaneous demand for health services for several reasons, except for early diagnosis. Thus, $50.0 \%$ of cases are diagnosed in advanced stages of the disease, maintaining high mortality rate, with no evidence of significant reductions $^{(14)}$.

In daily practice of the Basic Health Unit, Pap smear screening often does not follow what is recommended by the Brazilian Ministry of Health; professionals often adopt the annual frequency and women outside the recommended age have been screened $^{(2)}$. Such information may justify the lack of knowledge or inaccuracy of the frequency required to achieve Pap smear.

A study conducted in five rural areas in Malaysia to evaluate the practice of cervical cancer screening found that $48.9 \%$ of participants had undergone the Pap smear at least once in the last three years. It was also observed that younger women are less likely to take the exam ${ }^{(15)}$.

Health promotion actions occur predominantly in primary care, which is closer to the daily lives of women and accompanying them throughout their life. Thus, educational approaches must be present in the work process of Family Health Strategy teams, as it is essential to spread the need for conducting examinations and their frequency, as well as the warning signs that can indicate cancer ${ }^{(16)}$.

The Comprehensive Care Policy for Women's Health has promoted important advances in all life cycles, safeguarding the specificities of different age groups and different population groups. In this sense, in order to impact on the multiple factors that interfere in control actions for cervical cancer, it is important that care to women is guided by a multidisciplinary team with interdisciplinary practice, such as planning and scheduling control actions for cervical cancer, giving priority according to criteria of risk, vulnerability and inequality; performing control actions for cervical cancer with promotion, prevention, screening/early detection, diagnosis, treatment, rehabilitation and palliative care ${ }^{(17)}$.

The increased occurrence of this type of cancer is seen in underdeveloped countries. Thus, it indicates a strong association of cervical cancer with precarious life conditions, low levels of human development, absence or weakness of community education strategies and difficult access to public health services for the early diagnosis and treatment of underlying lesions ${ }^{(12)}$.

An awareness program on cervical cancer in two rural communities in China, in 2008, was developed with approximately 5,000 women, who were later submitted to evaluation in 2010 and 2011 through 
a questionnaire with ten basic questions about the said pathology. The awareness rate increased by four times, which shows that the program represents an effective and viable strategy for rural areas, favoring therefore the frequency and insertion of healthcare services $^{(18)}$.

Women living in rural areas are a vulnerable group due to low education, income and geographic location far from health services. So, these women should be understood as a priority group in the planning and execution of actions to control cervical cancer ${ }^{(13)}$. However, it was observed by women's reports that the lack of educational activities that should be promoted by the Family Health Strategy, which is a characteristic of health promotion, implies possible ignorance of the importance of cervical cancer screening on the prevention and screening/ early detection, thus increasing the vulnerability of this group to cervical cancer.

Public health services and actions that make up the Unified Health System are developed according to the comprehensive care that prioritizes preventive activities without disadvantages to care services. In a complementary way, the principles of the Unified Health System, such as universal access to health services at all levels of complexity and equality of health care, should ensure that Pap smear screening is performed free of charge to all women in the countryside ${ }^{(6)}$.

In Brazil, there is legislation that guarantees access to women, regardless of place of residence, to the cytological examination. Considering the high incidence and mortality related to cervical cancer, it is the responsibility of health managers and professionals to perform control actions, especially the Pap test, enabling early detection of this cancer ${ }^{(3)}$.

It is known that $40.0 \%$ of women of all ages have never undergone the examination. The justification for this low adherence relies on the difficulty of accessing health services and the way in which the procedure is performed, as well as on socioeconomic conditions and unawareness about gynecologic cancer. The cytological examination should be performed in the Basic Health Unit and is free for any woman; it has $100.0 \%$ of effectiveness in screening/early detection of cervical cancer ${ }^{(12)}$.

It is necessary a regional and hierarchical network of services to ensure comprehensive care to the female population, able to provide to women a humanized and full access to actions and qualified services to promote the prevention of cervical cancer, as well as access to the screening of underlying lesions, early diagnosis and appropriate, qualified and timely treatment ${ }^{(17)}$.

It is essential to provide care according to the reality of each population. In the countryside, it is believed that from the realization of joint efforts or availability of inputs, professionals can ensure access to the cytological examination, respecting guidelines and principles of the Unified Health System.

In planning the control actions to cervical cancer, managers should include conditions of access to the result of the examination by women as well as their presentation to the nurse. At that time, the nurse must perform the procedure according to the result. If the result determines referral to another service, it is fundamental that qualified referral is requested, with relevant data about the user, the clinical picture and the test results ${ }^{(9,19)}$.

The care model should organize and coordinate resources in the different levels of care in order to guarantee access to services and comprehensive care $^{(20)}$. The women living in the countryside should be seen as subjects in the uniqueness of their life stories, in sociocultural conditions in yearnings and expectations so that the health production is effective and accessible. In this perspective, the major role and shared responsibility of the government, health professionals and society is essential in the dissemination of knowledge and to ensure access to the cytological examination which, in turn, are key factors for reducing the incidence and mortality from cervical cancer. 


\section{Conclusion}

The study demonstrated that understanding the concept, importance and reason for seeking the health service for Pap smear screening was based on ideas of prevention and diagnosis, but it was insufficient. Access to examination is inadequate both in terms of health education on the subject and regarding its realization, due to inefficient or lack of planning of conduction of the examination and of educational practices by the Family Health Strategy team. This condition is a risk to the onset of cervical cancer in rural women.

\section{Acknowledgements}

To the Federal University of Piaui (Campus Amilcar Ferreira Sobral) and to the Center Continuing Education in Health of the Municipal Health of Floriano-PI, Brazil.

\section{Collaborations}

Carvalho ILN and Nunes RB contributed to the collection, organization and interpretation of data. Sousa IDB and Batista RDC contributed to drafting and relevant critical analysis of content. Sousa ASJ and Sousa CS contributed in the design, interpretation of data, scientific writing and final approval of the version to be published.

\section{References}

1. Instituto Nacional de Câncer José Alencar Gomes da Silva. Coordenação de Prevenção e Vigilância Estimativa 2016. Incidência do câncer no Brasil [Internet]. 2016 [citado 2016 jun. 02]. Disponível em:http://www.inca.gov.br/estimativa/2016/ estimativa-2016-v11.pdf

2. Amaral AF, Araújo ES, Magalhães JC, Silveira EA, Tavares SBN. Impacto da capacitação dos profissionais de saúde sobre o rastreamento do câncer do colo do útero em unidades básicas de saúde. Rev Bras Ginecol Obstetr. 2014; 36(4):182-7.
3. Silva DSM, Silva AMN, Brito LMO, Gomes SRL, Nascimento MDSB, Chein MBC. Rastreamento do câncer do colo do útero no Estado do Maranhão, Brasil. Ciênc Saúde Coletiva. 2015; 19(4):65-77.

4. Löwy I. Cancer, women, and public health: the history of screening for cervical cancer. Hist Ciênc Saúde-Manguinhos. 2010; 17(1):53-67.

5. Sá FC, Pires VAT. Citologia oncótica do colo do útero: atuação de equipes da estratégia saúde da família para alcançar as metas de cobertura. Rev Enferm Integrada. 2013; 6(1):1033-42.

6. Wunsch S, Oliveira GS, Garcia PR, Domingues BI. Coleta de citopatológico de colo uterino: saberes e percepções de mulheres que realizam o exame. Rev Enferm UFSM. 2011; 1(3):360-8.

7. Minayo MCS. O desafio do conhecimento - pesquisa qualitativa em saúde. São Paulo: Hucitec; 2008.

8. Moura ADA, Silva SMG, Farias LM, Feitoza AR. Conhecimento e motivações das mulheres acerca do exame de papanicolaou: subsídios para a prática de enfermagem. Rev Rene. 2010;11(1):94104.

9. Matão MEL, Miranda DB, Campos RHF, Machado AL, Ornelas ER. Percepção de mulheres acerca do exame colpocitológico. Rev Enferm Cent-Oeste Min. 2011; 1(1):47-58.

10. Nascimento LC, Nery IS, Antonia OS. Conhecimento cotidiano de mulheres sobre a prevenção do câncer do colo do útero. Rev Enferm UERJ. 2012; 20(4):476-80.

11. Sabeena S, Baht PV, Kamath V, Aswathyari S, Arunkumar G. Knowledge, attitude and practice about HPV Infection and its health effects among rural women in Karnataka, South India. Asian Pac J Cancer Prev. 2015; 16(12):5053-8.

12. Santos MA, Audickas CR, Coutinho CR, Silva J, Souza NL. A importância da prevenção do câncer do colo do útero: em pauta o exame o exame papanicolau. Rev Recien. 2014; 4(12):15-20.

13. Instituto Nacional de Câncer José Alencar Gomes da Silva. Coordenação Geral de Ações Estratégicas, Divisão de Apoio à Rede de Atenção Oncológica. Diretrizes brasileiras para o rastreamento do câncer do colo do útero. Rio de Janeiro: INCA; 2011. 
14. Gasperin SI, Boing AF, Kupek E. Cobertura e fatores associados à realização do exame de detecção do câncer de colo de útero em área urbana no Sul do Brasil: estudo de base populacional. Cad Saúde Pública. 2011; 27(7):1312-22.

15. Gan DEH, Dahlui M. Cervical screening uptake and its predictors among rural women in Malaysia. Singapore Med J. 2013; 54(3):163-8.

16. Cesarin MR, Piccoli JCE. Educação em saúde para a prevenção do câncer do colo do útero em mulheres do município de Santo Ângelo/RS. Ciênc Saúde Coletiva. 2011; 16(9):3925-32.

17. Lagana MTC, Silva MMP, Lima LF, França TLB. Cytological Abnormalities, Sexually Transmitted Diseases and Periodicity of Cervical Cancer Screening in a Basic Health Unit. Rev Bras Cancerol. 2013; 59(4):523-30.
18. Simayi D, Yang L, Li F, Wang YH, Amanguli A, Zahng W, et al. Implementing a Cervical Cancer Awareness Program in Low-income Settings in Western China: a Community-based Locally Affordable Intervention for Risk Reduction. Asian Pac J Cancer Prev. 2013; 14(12):7459-66.

19. Castro B, Ribeiro DP, Oliveira J, Pereira MB, Sousa JC, Yaphe J. Rastreio do câncer do colo do útero: limites etários, periodicidade e exame ideal: revisão da evidência recente e comparação com indicador de desempenho avaliado em Portugal. Ciênc Saúde Coletiva. 2014; 19(4):1113-22.

20. Thuler LCS, Bergmann A, Casado L. Perfil das pacientes com câncer do colo do útero no Brasil, 2000-2009: Estudo de Base Secundária. Rev Bras Cancerol. 2012; 58(3):351-7. 